\title{
The Role of Entrepreneurial Intentions, Perceived Risk and Perceived Trust in Crowdfunding Intentions
}

\author{
Mina Fanea-Ivanovici ${ }^{1}$, Hasnan Baber ${ }^{2 *}$ \\ ${ }^{1}$ Department of Economics and Economic Policies, Bucharest University of Economic Studies \\ 6 Piata Romana, District 1, Bucharest, 010372, Romania \\ E-mail.mina.ivanovici@economie.ase.ro, \\ ${ }^{2}$ Endicott College of International Studies, Woosong University \\ Daejeon-34606, South Korea \\ E-mail.h.baber@endicott.ac.kr; *corresponding author \\ cross'ref $^{\text {http://dx.doi.org/10.5755/j01.ee.32.5.29300 }}$
}

\begin{abstract}
Crowdfunding is a new financial and marketing tool, which is used to raise money for new projects and to promote innovative products. The aim of this paper is to investigate the influencing factors of crowdfunding intentions among students as future or current entrepreneurs. Drawing from the Theory of Planned Behaviour and the Unified Theory of Acceptance and Use of Technology, we analyse the data from two culturally and entrepreneurship-wise different countries, Romania and South Korea using PLS-SEM (N=441). Entrepreneurial intentions, perceived risk and perceived trust are found to positively influence crowdfunding intentions among business, economics and management students in both countries. We further check the influence of attitude towards entreprenurship, social norms and perceived behavioural control, entrepreneurial education and desire for success on entre-preneurial intentions, and report positive correlations for the whole analyzed sample. Moreover, social influence and facilitating conditions positively influence the entrepreneurs' perceived risk, and effort expectancy and performance expectancy positively influence perceived trust. Whereas the Romanian sample does not exhibit any influence of social norms on entrepreneurial intentions, entrepreneurial education is not correlated with entrepreneurial intentions in South Korea.
\end{abstract}

Keywords: Crowdfunding; Entrepreneurial Intentions; Theory of Planned Behavior; Entrepreneurial Education; Perceived Risk; Perceived Trust; Romania; South Korea;

\section{Introduction}

Crowdfunding (CF) has recently developed due to the rising market needs for alternative finance, on the one hand, and to legislators' efforts to accommodate this new financing tool, on the other hand. The US opened the gate in terms of CF enactment through the JOBS Act in 2012. Later on, other developed economies created the adequate legal framework for CF operation (Kuselias, 2020). Recently, the EU has adopted the Regulation on European Crowdfunding Service Providers (ECSP) for business (European Commission, n.d.). Inter alia, it requires "clear rules on information disclosures for project owners and crowdfunding platforms" and "rules on governance and risk management for crowdfunding platforms." Despite the large variations in legal frameworks, mitigating risk and fostering trust (Schwienbacher, 2019; Stemler, 2020) have been a constant market concern and at the very core of initiatives aimed to bolster crowdfunding intention (CI) and behavior. That is because backers and entrepreneurs are exposed to risks associated with lending, borrowing and equity. Success in raising funds depends on the perceived trust and risk linked with the platform from both market sides. Islam and Khan (2019) have investigated the role of social influence, facilitating conditions, effort expectancy and performance expectancy on the perceived risk and trust related to $\mathrm{CF}$ use. Rossi and
Vismara (2018) suggested that services offered by crowdfunding platforms do influence the annual number of successful campaigns and particluraly post-campaign services. However, creating a proper legal framework, addressing associated risks and enhancing trust, without considering the entrepreneurial intention (EI) are not enough to spur CF use for business development. Smith et al. (2019) stated that an entrepreneur is an individual who establishes and manages a business for profit and growth. Entrepreneurship is a broader term than the mere establishment of a business (Jena, 2020). It is series of cognitive and behavioural processes, which starts with the intention to be an entrepreneur. Intention to pursue any action or activity is a prerequisite for any behaviour. As described by Moriano et al. (2012, p. 165), $\mathrm{EI}$ is the "conscious state of mind" preceding the actual business action or behavior. EI develops over time through personal traits, external influences and education. Entrepreneurial education has a strong influence on students and shapes their intention to choose entrepreneurship as a career (Wei et al., 2019). This is because entrepreneurial education not only creates a positive attitude towards entrepreneurship, but also helps to take decisions that can improve the performance of the business (Ho et al., 2018). Intention models, along with the other additional influences of individual characteristics, such as desire for success, help to understand the direct antecedents of intention to start a business 
(Esfandiar et al., 2019). Krueger et al. (2000) stated that, of all intention theories, the theory of planned behavior (TPB) is the most preferred model to examine entrepreneurial intentions, as it offers a coherent structure that provides insights into understanding and predicting entrepreneurial intention. According to this theory, behavioral intentions depend on attitudes towards the behavior, social norms (SNs) and perceived behavioral control (PBC) (Azjen, 1991). Various valuable studies have applied TPB to investigate the entrepreneurial intention among university students (AlJubari et al. 2018; Fragoso et al., 2020; Laguia et al., 2019).We hereby aim to analyze the influence of perceived risk, perceived trust and EIs on CI in business and economics students in Romania and South Korea. The two countries exhibit different stages of entrepreneurship development: South Korea is innovation-driven, whereas Romania is opportunity driven, according to Roibu and Roibu (2016). Entrepreneurial intentions are then checked with the TPB components, entrepreneurial education and desire for success, whereas perceived trust will be checked with social influence and facilitating conditions, and perceived risk with effort expectancy and performance expectancy, which were taken from the unified theory of acceptance and use of technology (UTAUT) (Venkantesh et al., 2003). The findings of the study benefit both universities and academic curricula, in their endeavor to become more entrepreneurial and market-oriented, as well as platform owners, in order to better assess their functionalities so as to attract a larger number of entrepreneurs and investors, and to create an appealing and trustworthy image.

\section{Literature Review and Hypothesis Development}

\section{Theory of Planned Behaviour and Entrepreneurial Intentions (EIs)}

Attitudes towards behaviour, the first antecedent of intention, refer to 'the degree to which a person has a favourable or unfavourable evaluation or appraisal of the behaviour in question' (Ajzen, 1991, p. 188), SNs refer to 'the perceived social pressure to perform or not to perform the behaviour' (Ajzen, 1991, p. 188), and PBC is 'the perceived ease or difficulty of performing the behaviour' (Ajzen, 1991, p. 188) and it reflects previous experience and anticipated barriers. Various studies have investigated EI among the youths or students drawing on the TPB. Munir et al. (2019) concluded that the TPB components have a stronger explanatory power in emerging economies than in developed economies.Al-Jubari et al. (2019), Fragoso et al. (2020), Gieure et al. 2019, Munir et al., (2019), Nguyen et al. (2019) and Rodrigues et al. (2021) have found that there is a positive relationship between attitudes towards entrepreneurship or image of entrepreneurship (Bauboniene et al., 2018) and EIs. In addition, Esfandiar et al. (2019) proved that desirability for this activity is a moderate influencing factor. However, others studies contradict these findings, and argue that attitudes towards entrepreneurship cannot explain EIs in collectivist societies (Siu and Lo, 2011). Social norms (SNs), or the feedback from the relevant others, were found to have a positive influence on EIs (Al-Jubari et al., 2019; Gieure et al., 2019; Meoli et al., 2020; Munir et al., 2019). Bauboniene et al. (2018) tested the influence of SNs on EIs for Europe, and found a positive weak correlation, and Khusheed et al. (2018) found a significant correlation in both Europe and Asia. Paul et al. (2017) and Shinnar et al. (2012) postulated that country culture, which actually stands for SNs, is a significant predictor of EIs. Nevertheless, the study conducted by Esfandiar et al. (2019) and Perez-Fernandez et al. (2020) did not identify a significant correlation between the two variables.Perceived behavioral control (PBC), or else referred to as self-efficacy or feasibility, is yet another strong explanatory variable of EIs (Al-Jubari et al., 2019; Fragoso et al., 2020; Munir et al., 2019) or a weaker one (Esfandiar et al., 2019; Nguyen et al., 2019). A positive significant correlation has been found by Khusheed et al. (2018) in both Europe and Asia, while fear of failure in business was found to be a negative, but insignificant factor. Similar results were reported by Bauboniene et al. (2018), who found that students do not consider it an issue if they fail in business. Therefore, we formulate the following hypotheses pertaining to the TPB:

H1: Attitude towards entrepreneurship has a positive influence on EIs.

$\mathrm{H} 2$ : SNs have a positive influence on EIs.

$\mathrm{H} 3$ : PBC has a positive influence on EIs.

\section{Entrepreneurial Education and EIs}

The relationship between entrepreneurial education and EIs has been the object of extensive research. Altogether, studies indicate 'a significant but small correlation between entrepreneurial education and EIs' (Bae et al., 2014). Most studies have concluded that there is a positive correlation between entrepreneurial education and EIs (Jones et al., 2008; Bauboniene et al., 2018; Gieure et al., 2019; Ndofirepi, 2020; Nguyen et al., 2019; Wegner et al., 2020). While Gieure et al. (2019) argued that specialised education and training lead to EIs and university activities influence students' entrepreneurial mindset in this respect, Karimi et al. (2016) surprinsingly reached the conclusion that entrepreneurial education programmes have no significant effect on students' EIs. Other researchers (Fayolle \& Gailly, 2015) look at the impact of entrepreneurial education on EIs through the lens of previous exposure to entrepreneurship and find that it has a stronger impact on unexposed students than on students with some sort of entrepreneurship experience. Based on the extant literature, we formulate the following hypothesis:

\section{H4: EE has a positive influence on EI.}

\section{Desire for Success and EI}

Desire for success has been investigated and found to have a strong impact on entrepreneurial intentions among youths (Nguyen et al., 2019). Similar explanatory factors in the academic environment, such as learning orientation and passion for work, are conducive to desirability considerations that form EIs (De Clercq et al., 2013). While some studies indicate that personality traits, as is motivation to achieve, affect EIs more than other factors (EspirituOlmos and Sastre-Castillo, 2015), others showcase that personality traits have been tested to be poor predictors of EIs (Krueger et al., 2000). Given these conflicting views and conclusions, we set forth the following hypothesis within our proposed model: 
H5: Desire for success has a positive influence on EI.

\section{UTAUT and Perceived Risk and Trust}

Previous studies have investigated the influence of the UTAUT factors in the digital entrepreneurial environment (Kim \& Hall, 2020). Social influence is 'the degree to which an individual perceives that important others believe he or she would use the new system' (Venkantesh et al., 2003, p. 451), facilitating conditions refer to 'the degree to which an individual believes that an organizational or technical infrastructure exists to support use of the system' (Venkantesh et al., 2003, p. 452), effort expectancy reflects 'the degree of ease associated with the use of the system (Venkantesh et al., 2003, p. 450), and performance expectancy reflects 'the degree to which an individual believes that using the system will help him or her to attain gains in job performance' (Venkantesh et al., 2003, p. 447).

Thies et al. (2016) investigated the role of social influence on consumer decision making, while San Martin et al. (2021) identified that social consciousness and platform risk determine overall attitude towards $\mathrm{CF}$. Moreover, social influence is positively associated with $\mathrm{CF}$ success (Shneor et al., 2021). Moon and Hwang (2018) showed that CF intention is influenced by social influence, effort expectancy and perceived trust, and the same variables, along with performance expectancy and facilitating conditions are credited with influence power by Islam and Khan (2021).

In mobile payment, performance expectancy influences consumer behaviour, whereas social influence and facilitating conditions have a significant impact on intention to use (Patil et al., 2020). On a similar note, Slade et al. (2015) concluded that performance expectancy, social influence and perceived risk have a strong impact on nonusers to adopt this technology. Relationships have been discovered between perceived trust, effort expectancy, performance expectancy, social influence and facilitating conditions, and m-commerce adoption (Chong, 2013). Risk and trust influence on effort expectancy and performance expectancy were proved in NFC based mobile payment (Khalilzadeh et al., 2017).

Due to the still unexplored correlations between the UTAUT components, on one hand, and perceived risk and perceived trust, on the other hand, we will test the following four hypotheses within the proposed model:

H6: Social influence has a positive influence on perceived risk.

H7: Facilitating conditions have a positive influence on perceived risk.

H8: Effort expectancy has a positive influence on perceived trust.

H9: Performance expectancy has a positive influence on perceived trust.

\section{Perceived Risk, Perceived Trust and CI}

According to the trust theory, $\mathrm{CI}$ is influenced, inter alia, by trust in the platform (Kang et al., 2016; Zheng et al., 2016). Platform features that could instill trust or distrust refer to financial transparency and data privacy (Boeuf $e t a l$, 2014), the sufficiency of information provided throughout the campaign (Fanea-Ivanovici, 2018), platform expertise and trustworthiness (Moon \& Hwang, 2018). Furthermore, elements such as design, content, easiness of navigation, security, customer feedback, reliability, integrity could explain perceived trust or risk that further influence CI (Busse, 2019). Trust forms a main ingredient in the receipe of crowdfunding campaigns from either sides (backers and project owners) (Hossain \& Oparaocha, 2017). Extant studies reveal that perceived trust significantly explains CI (Kim et al., 2019, Kim et al., 2020; Moon \& Hwang, 2018; Rodriguez-Ricardo et al., 2019; Yang et al., 2019; Baber \& Fanea-Ivanovici, 2021). As for perceived risk, it was found to have a positive influence on CI (Zhao et al., 2017) or, on the contrary, to have no significant influence on CI (Kim et al., 2019). The largest majority of studies having investigated perceived risk and trust have done this from the perspective of backers/financiers CI (Steigenberger, 2017), and not from the perspective of future entrepreneurs' standpoint. Therefore, the present study aims to address this gap of knowledge by proposing the following two hypotheses:

H10: Perceived risk has a positive influence on CI

H11: Perceived trust has a positive influence on $\mathrm{CI}$

\section{EIs and CI}

Although less explored, the assumption that there is a positive correaltion between EIs and CI among students was dealt with by Baber (2022), and it was validated. The connections between EIs and CI were analysed in the qualitative research conducted by Busse (2018). The study proposes that entrepreneurial action is followed by $\mathrm{CF}$ action in order 'to boost their early stage level into the next one' (Busse, 2018, p. 306). In other words, the sequence EIs-CI is hereby discussed. In the same line of thought, we will check the following hypothesis:

H12: EIs have a positive influence on CI .

\section{Method}

\section{Research Context}

The sample of data was collected from two countries, Romania and South Korea. This research builds on previous research comparing the two countries in terms of entrepreneurship (Roibu \& Roibu, 2016). The sample consists of university students studying management, economics and business programmes. The students of these programs usually have an affinity towards entrepreneurship and acquire the required skills to operate the enterprise. There is a difference in the entrepreneurial disposition and intentions among the Asian and European students as suggested by Giacomin et al. (2011). The countries from these two regions were selected based on convenience sampling and the data was collected through a snowball sampling approach. Similar two-staged sampling was used by the previous studies of Baber \& Fanea-Ivanovici, (2021) and Bewley et al. (2014). The survey link was shared with students in online zoom meetings, by mail and the learning management system (LMS). The students were instructed to share this link with their friends and students in other courses. Further, a description was written in the beginning of survey to encourage students to share this link in their professional network to create a snowball effect. Participation in the survey 
was voluntary, anonymous, and no private data was collected, in compliance with the applicable General Data Protection Regulation (GDPR) regulations. The data was collected through an English administrated questionnaire as students were studying in international colleges. Sample

A total sample size of 441 was collected from both countries - Romania (224) and South Korea (217). Interestingly, females were in majority $(51 \%), 48 \%$ were males and $1 \%$ preferred not to disclose their gender. Most of the respondents were from the age group 18-21 (59\%), followed by the $22-25$ age group (32\%) and the rest $(9 \%)$ were above 27 years of age. Students were asked if they have any family or personal business experience. Around 34 $\%$ of the students said they had, and out of those, $20 \%$ had less than 1 year of experience in handling the business and $12 \%$ had between $1-5$ years. The sample $(16 \%)$ had some experience in raising funds or backing a project in $\mathrm{CF}$ as shown in Table 1.

Table 1

Demographic Characteristics

\begin{tabular}{|c|c|c|c|c|c|c|c|}
\hline & & \multicolumn{2}{|c|}{ Romania } & \multicolumn{2}{|c|}{ South Korea } & \multicolumn{2}{|c|}{ Total } \\
\hline Characteristic & Options & $n=224$ & \%age & $\mathrm{n}=\mathbf{2 1 7}$ & \%age & $n=441$ & \%age \\
\hline \multirow{3}{*}{ Gender } & Female & 134 & $59.82 \%$ & 94 & $43.32 \%$ & 229 & $51.84 \%$ \\
\hline & Male & 88 & $39.29 \%$ & 123 & $56.68 \%$ & 211 & $47.93 \%$ \\
\hline & Others & 2 & $0.89 \%$ & 0 & $0.00 \%$ & 2 & $0.46 \%$ \\
\hline \multirow{3}{*}{ Age } & $18-21$ & 165 & $73.66 \%$ & 96 & $44.24 \%$ & 262 & $59.35 \%$ \\
\hline & $22-25$ & 43 & $19.20 \%$ & 98 & $45.16 \%$ & 141 & $32.02 \%$ \\
\hline & 26 and above & 16 & $7.14 \%$ & 23 & $10.60 \%$ & 39 & $8.86 \%$ \\
\hline \multirow{6}{*}{ Business Experience } & With business experience, of which: & 81 & $36.16 \%$ & 68 & $31.34 \%$ & 149 & $33.87 \%$ \\
\hline & Less than 1 year experience & 53 & $23.66 \%$ & 34 & $15.67 \%$ & 87 & $19.78 \%$ \\
\hline & 1-5 years experience & 22 & $9.82 \%$ & 30 & $13.82 \%$ & 52 & $11.81 \%$ \\
\hline & 6-10 years experience & 3 & $1.34 \%$ & 2 & $0.92 \%$ & 5 & $1.14 \%$ \\
\hline & More than 10 years experience & 3 & $1.34 \%$ & 2 & $0.92 \%$ & 5 & $1.14 \%$ \\
\hline & Without business experience & 143 & $63.84 \%$ & 149 & $68.66 \%$ & 293 & $66.36 \%$ \\
\hline \multirow{2}{*}{$\begin{array}{l}\text { Crowdfunding } \\
\text { Experience }\end{array}$} & Yes & 42 & $18.75 \%$ & 29 & $13.36 \%$ & 71 & $16.14 \%$ \\
\hline & No & 182 & $81.25 \%$ & 188 & $86.64 \%$ & 371 & $84.08 \%$ \\
\hline
\end{tabular}

\section{Measures}

The items of constructs were taken from past studies as shown in Table 2. The data was analysed using the Partial Least Square structural equation modelling (PLS-SEM) approach through SmartPLS 3.2 software. PLS-SEM is useful in the earlier phases of theory development, it helps in exploration and theory development, it is convenient for testing a research framework where it is important to test the dependencies of the variable, predict the dependent variable, and where the structure is complex and data may lack normality (Hair Jr et al., 2020). The estimates of factor loading for each item in a construct and reliability of constructs are shown in Table 2. Factor loadings for all items exceed the minimum 0.70 thresholds. The loading value of PBC3 is slightly less than 0.7 , therefore it can be accepted. Cronbach's alpha and composite reliability criteria were used to evaluate the reliability of the data, and were confirmed as the values of both assessing criteria were above 0.7 (Hair et al., 2019). The construct 'desire for success' has an alpha value little less than 0.7 , but the composite reliability value was 0.823 , hence reliability will be established. To measure the convergent validity, AVE (average variance extracted) values were assessed. The values of AVE must exceed 0.5 minimum acceptable levels (Hair et al., 2019) as confirmed in Table 2, thus confirming that each item measures its corresponding construct. For assessing the divergent validity of the items, which implies two latent variables that are theorized to be different are also actually statistically different, Fornell-Larcker criteria were employed. To check the multicollinearity issue, VIF (variance inflation factor) is examined. If the VIF is 5.0 or lower, then data is not suffering from multicollinearity problem (Hair et al., 2019). All the values of VIF are below 5 (see Table 2). The square root of all values of AVEs is higher than the correlation between constructs; therefore, divergent validity is established (Fornell \& Larcker, 1981) as shown in appendix A. To further confirm the divergent validity, the HTMT ratio of correlations is evaluated. The divergent validity was established again as all values are below the acceptable maximum value threshold of 0.85 (Henseler et al., 2015). 
Internal Consistency and Measurement of Reflective Constructs Across Contexts

\begin{tabular}{|c|c|c|c|c|c|c|c|}
\hline \multirow{2}{*}{$\begin{array}{l}\text { Construct/ } \\
\text { Items* }\end{array}$} & \multirow{2}{*}{$\begin{array}{l}\text { Factor } \\
\text { Loading** }\end{array}$} & \multirow{2}{*}{ VIF } & \multicolumn{2}{|c|}{ Romania (n=224) } & \multicolumn{2}{|c|}{ South Korea $(n=217)$} & \multirow[b]{2}{*}{ f-value } \\
\hline & & & Mean & Std. dev & Mean & Std. dev & \\
\hline \multicolumn{8}{|c|}{ Attitude toward entrepreneurship (Cronbach's Alpha=0.894; CR=0.926; AVE=0.758) (Nguyen et al., 2019) } \\
\hline ATT1 & 0.898 & 2.962 & 3.82 & 1.056 & 3.88 & 1.000 & .418 \\
\hline ATT2 & 0.93 & 3.639 & 3.78 & 1.025 & 3.84 & 1.015 & .408 \\
\hline ATT3 & 0.898 & 2.807 & 3.95 & 1.083 & 3.96 & 1.009 & .028 \\
\hline ATT4 & 0.744 & 1.753 & 3.73 & 1.002 & 3.79 & 1.066 & .377 \\
\hline \multicolumn{8}{|c|}{ Social norms (Cronbach's Alpha=0.884; $\mathbf{C R}=\mathbf{0 . 9 3 0} ; \mathbf{A V E}=\mathbf{0 . 8 1 2})($ Farrukh et al., 2019) } \\
\hline SN1 & 0.925 & 2.91 & 3.74 & .901 & 3.70 & .991 & $.252 * * *$ \\
\hline SN2 & 0.89 & 2.41 & 3.88 & .965 & 3.82 & 1.048 & $.324 * *$ \\
\hline SN3 & 0.888 & 2.383 & 3.59 & .899 & 3.59 & .920 & .010 \\
\hline \multicolumn{8}{|c|}{ Perceived behavioral control (Cronbach's Alpha=0.738; CR=0.839; AVE=0.637) (Nguyen et al., 2019) } \\
\hline PBC1 & 0.922 & 1.537 & 3.04 & 1.008 & 3.09 & .991 & .298 \\
\hline PBC3 & 0.69 & 1.369 & 3.42 & .805 & 3.45 & .833 & .218 \\
\hline PBC4 & 0.765 & 1.531 & 3.54 & .763 & 3.55 & .854 & .050 \\
\hline \multicolumn{8}{|c|}{ Entrepreneurial education (Cronbach's Alpha $=0.816 ; \mathbf{C R}=\mathbf{0 . 8 7 6} ; \mathbf{A V E}=\mathbf{0 . 6 3 8})$ (Nguyen et al., 2019) } \\
\hline EED1 & 0.779 & 1.697 & 4.02 & .952 & 4.11 & 1.048 & .947 \\
\hline EED2 & $\mathbf{0 . 8 3 3}$ & 1.561 & 4.06 & .784 & 4.11 & .868 & .305 \\
\hline EED3 & 0.783 & 1.84 & 3.78 & .980 & 3.84 & 1.039 & .357 \\
\hline EED4 & 0.798 & 1.938 & 4.01 & .844 & 4.16 & .859 & $3.325 * * *$ \\
\hline \multicolumn{8}{|c|}{ Desire for success $($ Cronbach's Alpha=0.681; $\mathbf{C R}=\mathbf{0 . 8 2 3} ; \mathbf{A V E}=\mathbf{0 . 6 0 8})($ Mhango, 2006) } \\
\hline DFS1 & $\mathbf{0 . 8 4 3}$ & 1.401 & 4.05 & .866 & 4.09 & .906 & .162 \\
\hline DFS4 & 0.732 & 1.34 & 4.27 & .613 & 4.24 & .707 & .141 \\
\hline DFS6 & 0.76 & 1.266 & 3.78 & .884 & 3.94 & .885 & $3.762 * * *$ \\
\hline \multicolumn{8}{|c|}{ Entrepreneurial intentions (Cronbach's Alpha $=0.927 ; \mathbf{C R}=\mathbf{0 . 9 4 3} ; \mathbf{A V E}=\mathbf{0 . 7 3 2})($ Linan \& Chen, 2009) } \\
\hline EI1 & $\mathbf{0 . 8 0 5}$ & 2.434 & 3.35 & 1.039 & 3.41 & 1.015 & .400 \\
\hline EI2 & 0.869 & 3.003 & 3.46 & 1.079 & 3.52 & 1.081 & .254 \\
\hline EI3R & 0.838 & 2.63 & 3.78 & 1.048 & 3.86 & .929 & .724 \\
\hline EI4 & 0.9 & 4.032 & 3.88 & .976 & 3.88 & .920 & .003 \\
\hline EI5 & 0.868 & 3.564 & 3.75 & 1.041 & 3.77 & 1.019 & .024 \\
\hline EI6R & 0.852 & 2.747 & 3.79 & .973 & 3.85 & .981 & .385 \\
\hline \multicolumn{8}{|c|}{ Social Influence (Cronbach's Alpha=0.801; CR=0.883; AVE=0.716) (Kim \& Hall, 2020) } \\
\hline SIN1 & 0.863 & 1.897 & 3.04 & .792 & 2.90 & .855 & 3.057 \\
\hline SIN2 & 0.865 & 1.987 & 3.17 & .862 & 2.95 & .851 & 7.295 \\
\hline SIN3 & 0.808 & 1.504 & 3.34 & .843 & 3.28 & .833 & .616 \\
\hline \multicolumn{8}{|c|}{ Facilitating Conditions (Cronbach's Alpha $=\mathbf{0 . 8 1 6} ; \mathbf{C R}=\mathbf{0 . 8 7 9} ; \mathbf{A V E}=\mathbf{0 . 6 4 4})($ Islam \& Khan, 2021) } \\
\hline FC1 & 0.843 & 1.831 & 3.32 & .777 & 3.31 & .729 & .003 \\
\hline FC2 & 0.83 & 1.929 & 3.45 & .756 & 3.44 & .725 & .003 \\
\hline FC3 & 0.781 & 1.611 & 3.46 & .780 & 3.41 & .722 & .321 \\
\hline FC4 & 0.754 & 1.517 & 3.53 & .769 & 3.51 & .758 & .044 \\
\hline \multicolumn{8}{|c|}{ Effort Expectancy (Cronbach's Alpha $=\mathbf{0 . 8 1 5} ; \mathbf{C R}=\mathbf{0 . 8 7 8} ; \mathbf{A V E}=\mathbf{0 . 6 4 3})(\mathrm{Kim} \&$ Hall, 2020) } \\
\hline EE1 & $\mathbf{0 . 7 5 7}$ & 1.47 & 3.42 & .705 & 3.37 & .783 & .612 \\
\hline EE2 & 0.832 & 1.984 & 3.33 & .797 & 3.32 & .802 & .026 \\
\hline EE3 & $\mathbf{0 . 8 1 7}$ & 1.7 & 3.41 & .740 & 3.31 & .841 & 1.520 \\
\hline EE4 & 0.8 & 1.901 & 3.39 & .785 & 3.32 & .773 & 1.018 \\
\hline Performan & $\operatorname{tancy}$ (Cronb & Ipha $=0.8$ & $\mathbf{R}=\mathbf{0 . 8 9}$ & $\mathbf{E}=\mathbf{0 . 7 3 3 )}$ & i \& Hwang & & \\
\hline PE1 & 0.863 & 1.832 & 3.67 & .774 & 3.66 & .835 & .006 \\
\hline PE2 & 0.828 & 1.775 & 3.60 & .733 & 3.58 & .742 & .100 \\
\hline PE3 & 0.877 & 1.866 & 3.63 & .709 & 3.64 & .811 & .023 \\
\hline Perceived & abach's Alph & $0 ; C R=0$. & $\mathrm{AVE}=0$. & Islam \& Kh & 2021) & & \\
\hline PR1 & 0.769 & 1.417 & 3.13 & .902 & 3.18 & .885 & .288 \\
\hline PR2 & 0.824 & 1.49 & 3.17 & .808 & 3.26 & .810 & 1.318 \\
\hline PR3 & 0.791 & 1.308 & 2.98 & .828 & 3.00 & .874 & .048 \\
\hline Perceived 1 & onbach's Alp & 49; $C R=0$ & AVE $=0$ & (Moon \& H & g, 2018) & & \\
\hline PT1 & 0.866 & 1.792 & 3.23 & .773 & 3.23 & .812 & .001 \\
\hline PT2 & 0.878 & 1.795 & 3.31 & .709 & 3.35 & .803 & .274 \\
\hline PT3 & 0.694 & 1.285 & 3.20 & .815 & 3.28 & .769 & 1.129 \\
\hline Crowdfund & ations (Cronb & pha $=0.8$ & $C R=0.92$ & $\mathbf{E}=\mathbf{0 . 8 0 7})$ & $\mathrm{r}, 2020)$ & & \\
\hline BICF1 & 0.898 & 2.463 & 3.19 & .853 & 3.08 & .909 & 1.553 \\
\hline BICF2 & 0.915 & 2.817 & 3.20 & .883 & 3.08 & .849 & 2.205 \\
\hline BICF3 & 0.883 & 2.239 & 3.10 & .893 & 2.98 & .935 & 1.940 \\
\hline
\end{tabular}

Note. $C R=$ Composite reliability; $A V E=$ average variance extracted; VIF = variance inflation factor; Std. dev= standard deviation; *Items of the construct are shown in appendix $A ;{ }^{* *} p<0.05 ; * * * p<0.10$. 


\section{Results}

\section{The Structural Model}

After the measurement model was estimated, the structural model was also assessed. In PLS-SEM, the goodnessof-fit of the estimated model is evaluated by assessing goodness-of-fit indices through beta $(\beta)$, P-values, effect sizes $\left(\mathrm{f}^{2}\right)$, and $\mathrm{R}^{2}$, as suggested by Hair et al. (2020). The structural model specifies the causal relationships between constructs in the model (Hair Jr et al., 2020), which is shown in Table 3 along with effect sizes $\left(\mathrm{f}^{2}\right)$. Lately, Henseler et al. (2016b) suggested using the standardized root mean square residual (SRMR) as the only theoretical model fit criterion. SRMR value of this study is 0.051 , which is $\leq 0.1$ and treated as satisfactory for PLS path models (Kock, 2020).
The $\mathrm{R}^{2}$ values of perceived risk, perceived trust, entrepreneurial intentions and crowdfunding intentions are 0.324 , $0.278,0.404$ and 0.308 , respectively, which implies the variance in these constructs is reasonably explained by the predicting constructs, as shown in Figure 1. Apart from the above-suggested model fit indices, we also conducted a fitness of the structural model using Amos v22. Various indices, e.g. Chi-square, Goodness-of-fit index (GFI), Adjusted Goodness-of-fit index (AGFI), Comparative Fit Index (CFI), Root mean square residuals (RMSR), Root mean square error of approximation (RMSEA), TLI (Tucker Lewis Index), and Parsimony normed fit index (PNFI), were considered. The measured values of fit indices have revealed the good structural model fit to the data for the proposed research model in this study as shown in Table 3.

Table 3

Goodness-of-fit Estimation

\begin{tabular}{|c|c|c|c|c|c|c|c|c|}
\hline Fit index & $\chi^{2 / \mathrm{df}}$ & GFI & AGFI & CFI & RMSR & RMSEA & TLI & PNFI \\
\hline Recommended value (Hair et al., 2010) & $<3$ & $>0.85$ & $>0.80$ & $>0.90$ & $<0.10$ & $<0.08$ & $>0.90$ & $>0.60$ \\
\hline Structural model & 1.954 & .851 & .830 & .915 & .055 & .047 & .907 & .769 \\
\hline
\end{tabular}

\section{Testing Hypotheses}

The significance of the model was estimated based on path coefficients $(\beta), T$ values, $P$-values, and $\mathrm{f}^{2}$. All our hypotheses (H1-H12) are supported by the results reported in Table 4. There is a negative significant relationship between PBC and EIs (H4), which is contradicting our supposed hypothesis to be positive. Although we did not hypothesize the indirect or mediating relationships, however, it will be interesting to see the mediating role of EI, perceived risk and perceived trust on the crowdfunding intentions. All the factors mentioned are playing a significant mediating role except $\mathrm{PBC}$ on $\mathrm{CI}$, as shown in Table 4.

Table 4

Estimation of Path Relationships

\begin{tabular}{|c|c|c|c|c|c|c|}
\hline H\# & Direct Relationships & $\boldsymbol{\beta}$ & T- Values & P Values & $F^{2}$ & Remarks \\
\hline H1 & Attitude $\rightarrow$ EI & 0.254 & 5.33 & 0.000 & 0.084 & Supported \\
\hline $\mathrm{H} 2$ & Social norms $\rightarrow$ EI & 0.142 & 2.442 & 0.015 & 0.027 & Supported \\
\hline $\mathrm{H} 3$ & Perceived behavioral control $\rightarrow$ EI & -0.103 & 1.919 & 0.056 & 0.016 & Supported** \\
\hline $\mathrm{H} 4$ & Entrepreneurial Education $\rightarrow$ EI & 0.368 & 8.154 & 0.000 & 0.179 & Supported \\
\hline H5 & Desire for success $\rightarrow \mathrm{EI}$ & 0.182 & 3.933 & 0.000 & 0.045 & Supported \\
\hline H6 & Social Influence $\rightarrow$ PR & 0.245 & 5.731 & 0.000 & 0.068 & Supported \\
\hline $\mathrm{H} 7$ & Facilitating Conditions $\rightarrow$ PR & 0.410 & 8.926 & 0.000 & 0.192 & Supported \\
\hline H8 & Effort Expectancy $\rightarrow$ PT & 0.359 & 8.097 & 0.000 & 0.150 & Supported \\
\hline H9 & Performance Expectancy $\rightarrow$ PT & 0.267 & 5.374 & 0.000 & 0.082 & Supported \\
\hline $\mathrm{H} 10$ & PR $\rightarrow$ Crowdfunding intentions & 0.253 & 4.428 & 0.000 & 0.054 & Supported \\
\hline H11 & PT $\rightarrow$ Crowdfunding intentions & 0.308 & 5.422 & 0.000 & 0.081 & Supported \\
\hline \multirow[t]{11}{*}{$\mathrm{H} 12$} & EI $\rightarrow$ Crowdfunding intentions & 0.126 & 2.569 & 0.010 & 0.021 & Supported \\
\hline & Indirect Relationships & & & & & \\
\hline & Attitude $\rightarrow$ EI $\rightarrow$ CI & 0.032 & 2.358 & 0.019 & & Supported \\
\hline & Social norms $\rightarrow \mathrm{EI} \rightarrow \mathrm{CI}$ & 0.018 & 1.740 & 0.083 & & Supported*** \\
\hline & Perceived behavioral control $\rightarrow$ EI $\rightarrow$ CI & -0.013 & 1.533 & 0.126 & & Not- Supported \\
\hline & Entrepreneurial Education $\rightarrow$ EI $\rightarrow$ CI & 0.046 & 2.393 & 0.017 & & Supported \\
\hline & Desire for success $\rightarrow \mathrm{EI} \rightarrow \mathrm{CI}$ & 0.023 & 2.088 & 0.037 & & Supported \\
\hline & Social Influence $\rightarrow$ PR $\rightarrow$ CI & 0.062 & 3.186 & 0.002 & & Supported \\
\hline & Facilitating Conditions $\rightarrow$ PR $\rightarrow$ CI & 0.104 & 3.838 & 0.000 & & Supported \\
\hline & Effort Expectancy $\rightarrow$ PT $\rightarrow$ CI & 0.111 & 4.562 & 0.000 & & Supported \\
\hline & Performance Expectancy $\rightarrow$ PT $\rightarrow$ CI & 0.082 & 3.290 & 0.001 & & Supported \\
\hline
\end{tabular}

** Supported but negative at $10 \%$ significance level. ** Supported at $10 \%$ significance level.

$E I=$ Entrepreneurial intentions; $P R=$ Perceived Risk; $P T=$ Perceived Trust; $C I=$ Crowdfunding intentions 


\section{Multi-Group Analysis (MGA)}

To maintain the validity of outcomes and conclusions, Henseler et al. (2016a) developed the measurement invariance of composite models (MICOM) procedure, which builds on the scores of the latent variable that fit with the trait of composite modelling in partial least squares path modelling (PLSPM) (Cheah et al., 2020). We conducted MICOM and assessed permutation's p-values that were larger than 0.05 except for perceived risk and social influence, indicating the compositional invariance was established. Now we can confidently compare standardized path coefficients across the groups through MGA in PLSPM.

Multi-group analysis (MGA) or between-group analysis is a means to test predefined (also known as a priori) data groups to verify the existence of significant differences across group-specific parameter estimates (e.g., outer weights, outer loadings, and path coefficients) (Hair et al., 2021). The model was then estimated for the two groupsRomania and South Korea- independently to verify the significance of the structural relations as shown in the Table 5. For Romania, all the hypotheses are supported except H2 and $\mathrm{H} 3$ and for the South Korean region, all the hypotheses are supported except H3 and H4. Perceived behavioural control has no significant effect on the entrepreneurial intentions in two regions independently, i.e. Romania and South Korea. Social norms show no positive relationship with entrepreneurial intentions in Romania, and entrepreneurial education shows no positive link with entrepreneurial intentions in South Korea. The results of the MGA were evaluated using the Henseler-MGA nonparametric technique. This technique assesses the differences between the path coefficients among two regions, and is used to estimate group differences in PLS-SEM (Hair et al., 2019). After estimating relationships of model for both regions- Romania and South Korea- the next step was to analyse both regions concurrently for comparison. As illustrated in Table 5, no significant differences can be comprehended for the structural relationships hypothesized in all hypotheses, except social norms on entrepreneurial intentions, as the p-values of the difference in path coefficients between the Romanian and South Korean groups are all above 5\%. Therefore, we report a significant difference in the social norms and its influence on entrepreneurial intentions in these two countries. The overall estimates and individual region estimates along with $\mathrm{R}^{2}$ values are shown in Figure 1 .

Table 5

PLS-MGA Results

\begin{tabular}{|c|c|c|c|c|c|c|c|c|c|c|}
\hline & \multicolumn{3}{|c|}{ Romania } & \multicolumn{3}{|c|}{ South Korea } & \multicolumn{3}{|c|}{ Romania - South Korea } & \multirow[b]{2}{*}{ Remarks } \\
\hline Relationships & 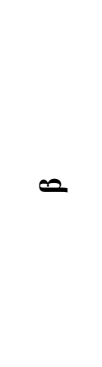 & 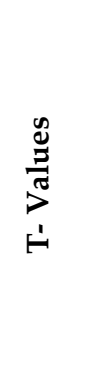 & $\begin{array}{l}\stackrel{0}{\Xi} \\
\frac{\Xi}{\pi} \\
D^{2}\end{array}$ & $\infty$ & $\frac{\stackrel{D}{\Xi}}{\stackrel{\Xi}{\beth}}$ & $\begin{array}{l}\stackrel{\mathscr{D}}{\Xi} \\
\stackrel{\Xi}{J} \\
0\end{array}$ & 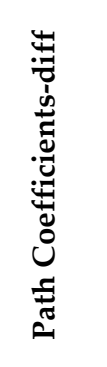 & 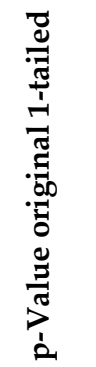 & 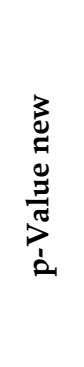 & \\
\hline Attitude $\rightarrow$ EI & 0.157 & 2.651 & 0.008 & 0.325 & 4.966 & 0.000 & -0.168 & 0.970 & 0.059 & $\begin{array}{c}\text { No } \\
\text { difference }\end{array}$ \\
\hline Social norms $\rightarrow E I$ & 0.012 & 0.170 & 0.865 & 0.226 & 2.761 & 0.006 & -0.214 & 0.978 & 0.043 & $\begin{array}{c}\text { Significant } \\
\text { difference }\end{array}$ \\
\hline $\begin{array}{l}\text { Perceived behavioral control } \\
\rightarrow E I\end{array}$ & -0.080 & 1.183 & 0.237 & -0.108 & 1.267 & 0.206 & 0.028 & 0.380 & 0.759 & $\begin{array}{c}\text { No } \\
\text { difference }\end{array}$ \\
\hline $\begin{array}{l}\text { Entrepreneurial Education } \\
\rightarrow E I\end{array}$ & 0.136 & 2.006 & 0.045 & 0.114 & 1.632 & 0.103 & 0.022 & 0.412 & 0.823 & $\begin{array}{c}\text { No } \\
\text { difference }\end{array}$ \\
\hline Desire for success $\rightarrow E I$ & 0.260 & 3.299 & 0.001 & 0.145 & 2.745 & 0.006 & 0.115 & 0.116 & 0.232 & $\begin{array}{c}\text { No } \\
\text { difference } \\
\end{array}$ \\
\hline Social Influence $\rightarrow P R$ & 0.222 & 3.962 & 0.000 & 0.276 & 4.377 & 0.000 & -0.054 & 0.748 & 0.504 & $\begin{array}{c}\text { No } \\
\text { difference }\end{array}$ \\
\hline $\begin{array}{l}\text { Facilitating Conditions } \rightarrow \\
P R\end{array}$ & 0.492 & 8.016 & 0.000 & 0.331 & 4.856 & 0.000 & 0.161 & 0.038 & 0.077 & $\begin{array}{c}\text { No } \\
\text { difference } \\
\end{array}$ \\
\hline Effort Expectancy $\rightarrow P T$ & 0.276 & 3.668 & 0.000 & 0.445 & 7.573 & 0.000 & -0.169 & 0.961 & 0.078 & $\begin{array}{c}\text { No } \\
\text { difference }\end{array}$ \\
\hline $\begin{array}{l}\text { Performance Expectancy } \rightarrow \\
\text { PT }\end{array}$ & 0.286 & 4.461 & 0.000 & 0.251 & 3.517 & 0.000 & 0.036 & 0.357 & 0.714 & $\begin{array}{c}\text { No } \\
\text { difference }\end{array}$ \\
\hline $\begin{array}{l}P R \rightarrow \text { Crowdfunding } \\
\text { intentions }\end{array}$ & 0.143 & 1.761 & 0.079 & 0.363 & 4.518 & 0.000 & -0.220 & 0.972 & 0.056 & $\begin{array}{c}\text { No } \\
\text { difference }\end{array}$ \\
\hline $\begin{array}{l}P T \rightarrow \text { Crowdfunding } \\
\text { intentions }\end{array}$ & 0.358 & 4.568 & 0.000 & 0.252 & 3.172 & 0.002 & 0.106 & 0.170 & 0.340 & $\begin{array}{c}\text { No } \\
\text { difference }\end{array}$ \\
\hline $\begin{array}{l}\text { EI } \rightarrow \text { Crowdfunding } \\
\text { intentions }\end{array}$ & 0.360 & 5.343 & 0.000 & 0.354 & 5.586 & 0.000 & 0.006 & 0.478 & 0.956 & $\begin{array}{c}\text { No } \\
\text { difference }\end{array}$ \\
\hline
\end{tabular}




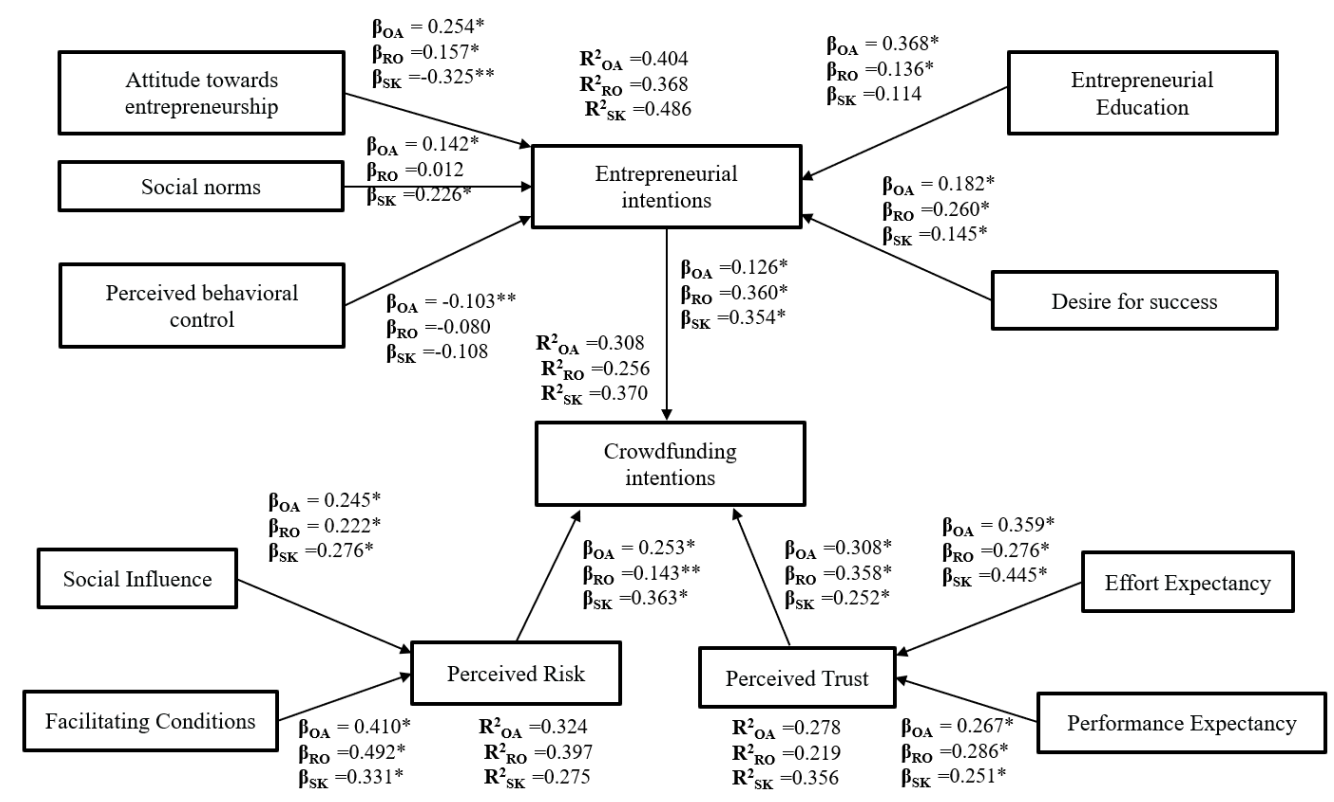

Figure 1. The structural model

*Significance level where p-value $<0.05$; ** Significance level where p-value $<0.10$;

$\boldsymbol{\beta}_{\boldsymbol{O} \boldsymbol{A}}$ and $\boldsymbol{R}^{2} \boldsymbol{O A}$ for Over-all Sample; $\boldsymbol{\beta}_{\boldsymbol{R} O}$ and $\boldsymbol{R}^{2}{ }_{\boldsymbol{R} O}$ for Romania; $\boldsymbol{\beta}_{\boldsymbol{S K}} \boldsymbol{A N D} \boldsymbol{R}^{2} \boldsymbol{S K}$ for South Korea

\section{Discussion}

The study confirms the proposed model, with few exceptions. Therefore, the TPB proves to be useful in explaining EIs among students. Within the present study, the nondebatable component of the TPB is attitude towards entrepreneurship, which holds for both countries considered separately, but also for the entire sample. The same was found by Al-Jubari et al. (2019), Fragoso et al. (2020), Gieure et al. 2019, Munir et al., (2019), Nguyen et al. (2019), Bauboniene et al. (2018) and Esfandiar et al. (2019). Such conclusion would place Romania and Korea among the noncollectivist countries (Siu and Lo, 2011), but such affirmation is yet to be checked in future research. PBC, however, is negatively correlated with EIs, contrary to our assumption. The perception of non-feasibility does not hamper business students from considering entrepreneurship, which could reflect a less risk-adverse attitude. Moreover, PBC has no significant influence on EIs in the two countries, analysed separately. In Romania, SNs do not play an important role in students' EI, in contradiction with the majority of studies in this area (Al-Jubari et al., 2019; Gieure et al., 2019; Meoli et al., 2020; Munir et al., 2019), bringing this study closer to the research of Bauboniene et al. (2018). They investigated this factor Lithuania, which is a similar country to Romania both in terms of historic (post-communist society) and economic background (recent members of the European Union) and found a positive, but weak correlation. Our findings are in line with the conclusions drawn by Esfandiar et al. (2019) in this respect, i.e. no correlation between SNs and EI. SNs have a positive influence on EIs in South Korea, but no influence in Romania - thus disclosing substantial country culture differences (Paul et al., 2017; Shinnar et al., 2012). Indeed, the two countries present significant differences in terms of SNs, which confirms cultural differences. Roibu and Roibu (2016) suggested that strict social environment is one of the factors in South Korea which restrict women to be an entrepreneur as compared to the social influence in Romania.

In South Korea, however, entrepreneurial education is not an explanatory factor for EIs (Karimi et al., 2016), contrary to most prior research (Bauboniene et al., 2018; Gieure et al., 2019; Ndofirepi, 2020; Nguyen et al., 2019; Wegner et al., 2020). Probably attitudes towards entrepreneurship in a society promoting entrepreneurship weigh more in students' decisions than formal education, which in the Asian country, is not credited with the capacity to form EIs. Lee et al. (2005) suggested that entrepreneurial education has shown a significant improvement in terms of acknowledgement of the importance of entrepreneurial education, after taking the course among Korean students as compared to the Americans. However, the hypothesis is checked for the entire sample, as previously reported by (Bauboniene et al., 2018; Gieure et al., 2019; Ndofirepi, 2020; Nguyen et al., 2019; Wegner et al., 2020). It is no surprise that desire for success is an explanatory factor for EIs (Nguyen et al., 2019). This is actually the transposition of a personal trait at professional level.

Perceived risk is positively associated with social influence and facilitating conditions, whereas perceived trust is positively correlated with effort expectancy and performance expectancy. Therefore, the hypothesized correlations have been checked, which extends the current knowledge, currently limited to m-commerce and mobile payment, to the crowdfunding area. The results highlight the importance of the crowdfunding platform and its easiness to handle projects and enhance trust in business entrepreneurs. Perceived risk is reduced by the approval of class, family and friends, who can recommend crowdfunding as a source of funds, which is true for both countries. Facilitating conditions of 
the platform, which include guiding the entrepreneurs to post their project, providing the necessary training to attract more backers, facilitating the interaction with backers, providing regular updates about the project and, ultimately, helping in promoting business, will reduce the risk of the entrepreneur.

Both perceived risk (surprisingly) and perceived trust positively influence crowdfunding intention. Crowdfunding implies raising funds from a large community, therefore the risk is somewhat borne by investors, which are individuals that are willing to finance a certain project or start-up with a small amount in the total amount required. For an entrepreneur, the risk of failure may only affect the implementation time and credibility, but does not imperil own funds. Last but not least, entrepreneurial intentions are an explanatory factor for crowdfunding intentions. With the rapid advancements of the digital transformation, would-be entrepreneurs have started to consider alternative financial and marketing tools, both of which being encapsulated in crowdfunding. Students, mainly those who are surrounded by technology and internet, find this source of funding convenient and easy to procure as compared to the traditional funding channels.

\section{Theoretical Implications}

The paper is original from a theoretical standpoint as it proposes a novel model, in which UTAUT and perceived risk and perceived trust correlations are explored in the crowdfunding context. To the best of our knowledge, little has been researched in this respect. Also, the TPB and UTAUT theories are both used to explain crowdfunding and entrepreneurial intentions among European and Asian students, while identifying differences that may be due to the contrasting cultural backgrounds.
From an academic point of view, faculty management and members of Business and Economics universities will benefit from the present findings. This is because the latter confirm the need to keep academic curricula to date with the latest developments of digital markets, and update the taught content accordingly. After all, students' future entrepreneurial intentions depend on the specialized education they receive during the study programs and awareness about alternative financial products is essential in starting new ventures.

The UTAUT-related correlations to perceived risk and perceived trust can prove useful to practitioners. Thus, the fact that perceived risk is found to be positively influenced by social influence and facilitating conditions provides platform owners with insights as to how better design the platform, in terms of image creation, online and offline promotion, usability, networking. Moreover, as perceived trust is positively correlated with effort expectancy and performance expectancy, platform owners and interested investors will know how to address key questions regarding the proposed project and how to check its feasibility.

\section{Conclusions}

Crowdfunding as a novel FinTech tool is creating new business opportunities for well-established firms to finance new projects, but also for start-ups and unexperienced entrepreneurs (undergraduates and fresh graduates). Therefore, it is of utmost importance for entrepreneurs to be aware of it, and entrepreneurial education plays an important role in such matter. The current paper investigates the entrepreneur-side perceived risk and perceived trust stemming from the UTAUT theory in crowdfunding intentions, along with the TPB, entrepreneurial education and desire for success in the formation of EIs, as a preliminary phase to CI. We have found that cultural differences in Asian and European countries provide contrasting views on the role of SNs, $\mathrm{PBC}$ and entrepreneurial education on EIs.

\section{Practical Implications}

\section{Acknowledgement}

This research is funded by Woosong University Academic Research in 2021

Appendix A- Assessment of Discriminant Validity using Fornell-Larcker Criteria

\begin{tabular}{|c|c|c|c|c|c|c|c|c|c|c|c|c|c|}
\hline & 1 & 2 & 3 & 4 & 5 & 6 & 7 & 8 & 9 & 10 & 11 & 12 & 13 \\
\hline Attitude & 0.871 & & & & & & & & & & & & \\
\hline Social norms & 0.426 & 0.901 & & & & & & & & & & & \\
\hline $\begin{array}{l}\text { Perceived } \\
\text { behavioral control }\end{array}$ & 0.227 & 0.257 & 0.798 & & & & & & & & & & \\
\hline $\begin{array}{l}\text { Entrepreneurial } \\
\text { Education }\end{array}$ & 0.191 & 0.106 & -0.079 & 0.799 & & & & & & & & & \\
\hline Desire for success & 0.110 & 0.072 & -0.082 & 0.432 & 0.780 & & & & & & & & \\
\hline $\begin{array}{l}\text { Entrepreneurial } \\
\text { intentions }\end{array}$ & 0.382 & 0.277 & -0.052 & 0.519 & 0.388 & 0.856 & & & & & & & \\
\hline Social Influence & 0.113 & 0.092 & -0.043 & 0.195 & 0.077 & 0.194 & 0.846 & & & & & & \\
\hline $\begin{array}{l}\text { Facilitating } \\
\text { Conditions }\end{array}$ & 0.050 & 0.122 & -0.072 & 0.299 & 0.228 & 0.225 & 0.479 & 0.803 & & & & & \\
\hline Effort Expectancy & 0.103 & 0.098 & -0.035 & 0.242 & 0.217 & 0.255 & 0.383 & 0.466 & 0.802 & & & & \\
\hline $\begin{array}{l}\text { Performance } \\
\text { Expectancy }\end{array}$ & 0.039 & 0.034 & -0.086 & 0.355 & 0.222 & 0.214 & 0.323 & 0.383 & 0.404 & 0.856 & & & \\
\hline
\end{tabular}


Mina Fanea-Ivanovici, Hasnan Baber. The Role of Entrepreneurial Intentions, Perceived Risk and Perceived Trust in ...

\begin{tabular}{|l|c|c|c|c|c|c|c|c|c|c|c|c|c|}
\hline & $\mathbf{1}$ & $\mathbf{2}$ & $\mathbf{3}$ & $\mathbf{4}$ & $\mathbf{5}$ & $\mathbf{6}$ & $\mathbf{7}$ & $\mathbf{8}$ & $\mathbf{9}$ & $\mathbf{1 0}$ & $\mathbf{1 1}$ & $\mathbf{1 2}$ & $\mathbf{1 3}$ \\
\hline Perceived Risk & 0.110 & 0.126 & -0.092 & 0.182 & 0.112 & 0.256 & 0.441 & 0.527 & 0.403 & 0.289 & 0.795 & & \\
\hline Perceived Trust & 0.086 & 0.121 & -0.115 & 0.212 & 0.124 & 0.240 & 0.450 & 0.612 & 0.467 & 0.412 & 0.633 & 0.817 & \\
\hline $\begin{array}{l}\text { Crowdfunding } \\
\text { intentions }\end{array}$ & 0.083 & 0.099 & -0.090 & 0.134 & 0.062 & 0.264 & 0.577 & 0.413 & 0.333 & 0.410 & 0.480 & 0.498 & 0.898 \\
\hline
\end{tabular}

\section{References}

Al-Jubari, I., Hassan, A., \& Linan, F. (2019). Entrepreneurial intention among University students in Malaysia: integrating selfdetermination theory and the theory of planned behaviour. International Entrepreneurship and Management Journal, 15(4), 1323-1342. https://doi.org/10.1007/s11365-018-0529-0

Ajzen, I. (1991). The theory of planned behaviour. Organizational Behavior and Human Decision Processes, 50(2), $179-211$. https://doi.org/10.1016/0749-5978(91)90020-T

Baber, H. (2022): Entrepreneurial and Crowdfunding Intentions of Management Students in South Korea. World Journal of Entrepreneurship, Management and Sustainable Development, 18(1), 1-14. https://doi.org/10.47556/J.WJEMSD.18.1.2022.3

Baber, H., \& Fanea-Ivanovici, M. (2021). Motivations behind backers' contributions in reward-based crowdfunding for movies and web series. International Journal of Emerging Markets. https://doi.org/10.1108/IJOEM-01-2021-0073.

Baber, H. (2020). Intentions to participate in political crowdfunding-from the perspective of civic voluntarism model and theory of planned behavior. Technology in Society, 63, 101435. https://doi.org/10.1016/j.techsoc.2020.101435

Bae, T. J., Qian, S., Miao, C., \& Fiet, J. O. (2014). The Relationship Between Entrepreneurship Education and Entrepreneurial Intentions: A Meta-Analytic Review. Entrepreneurship Theory and Practice, 38(2), 217-254. https://doi.org/10.11 11\%2Fetap.12095

Bauboniene, Z., Hahn, K. H., Puksas, A., \& Malinauskiene, E. (2018). Factors influencing student entrepreneurship intentions: the case of Lithuanian and South Korean universities. In M. Tvaronavičiene (Ed.), Entrepreneurship and Sustainability Issues, Entrepreneurship and Sustainability Center, 6(2), 854-871. https://doi.org/10.9770/jesi.2018.6.2(26)

Bewley, A., Burrage, D. M., Ersser, S. J., Hansen, M., \& Ward, C. (2014). Identifying individual psychosocial and adherence support needs in patients with psoriasis: a multinational two-stage qualitative and quantitative study. Journal of the European academy of dermatology and venereology, 28(6), 763-770. https://doi.org/10.1111/jdv.12174

Boeuf, B., Darveau, J., \& Legoux, R. (2014). Financing creativity: Crowdfunding as a new approach for theatre projects. International Journal of Arts Management, 16(3), 33-48.

Burtch, G., Ghose, A., \& Wattal, S. (2016). Secret Admirers: An Empirical Examination of Information Hiding and Contribution Dynamics in Online Crowdfunding. Information Systems Research, 27(3), 478-496. https://doi.org/10.1287/isre. 2016.0642

Busse, V. (2018). Crowdfunding - An Empirical Study on the Entrepreneurial Viewpoint. Advances in Intelligent Networking and Collaborative Systems, Springer International Publishing, 306-318. https://doi.org/10.1007/978-3-319-98557-2_28

Cheah, J. H., Thurasamy, R., Memon, M. A., Chuah, F., \& Ting, H. (2020). Multigroup Analysis using SmartPLS: Step-by-Step Guidelines for Business Research. Asian Journal of Business Research Volume, 10(3), 1-19, https://DOI.org/ 10.14707/ajbr.200087

Chong, A. Y. L. (2013). Predicting m-commerce adoption determinants: A neural network approach. Expert Systems with Applications, 40 (2), 523-530. https://doi.org/10.1016/j.eswa.2012.07.068

De Clercq, D., Honig, B., \& Martin, B. (2012). The roles of learning orientation and passion for work in the formation of entrepreneurial intention. International Small Business Journal: Researching Entrepreneurship, 31(6), $652-676$. https://doi.org/10.1177\%2F0266242611432360

Esfandiar, K., Sharifi-Tehrani, M., Pratt, S., \& Altinay, L. (2019). Understanding entrepreneurial intentions: A developed integrated structural model approach. Journal of Business Research, 94, 172-182. https://doi.org/10.1016/j.jbusres. 2017.10.045

European Commission (n.d.). Crowdfunding. Available from internet: https://ec.europa.eu/info/business-economy-euro/growthand-investment/financing-investment/crowdfunding_en

Fanea-Ivanovici, M. (2018). Transparency of Financial Information on Crowdfunding Platforms - A Prerequisite for Successful Funding Campaigns. In International Conference KNOWLEDGE-BASED ORGANIZATION, Walter de Gruyter GmbH, 24 (2), 37-42. https://doi.org/10.1515/kbo-2018-0063

Farrukh, M., Lee, J. W. C., Sajid, M., \& Waheed, A. (2019). Entrepreneurial intentions: The role of individualism and collectivism in perspective of theory of planned behaviour. Education + Training, 61 (7/8), 984-1000. https://doi.org/10.1108/ET-092018-0194

Fayolle, A., \& Gailly, B. (2013). The Impact of Entrepreneurship Education on Entrepreneurial Attitudes and Intention: Hysteresis and Persistence. Journal of Small Business Management, 53 (1), 75-93. https://doi.org/10.1111/jsbm.12065 
Fornell, C., \& Larcker, D. F. (1981). Evaluating Structural Equation Models with Unobservable Variables and Measurement Error. Journal of Marketing Research, 18(1), p. 39. https://doi.org/10.2307/3151312

Fragoso, R., Rocha-Junior, W., \& Xavier, A. (2019). Determinant factors of entrepreneurial intention among university students in Brazil and Portugal. Journal of Small Business \& Entrepreneurship, 32 (1), 33-57. https://doi.org/10.1080/08276331. 2018.1551459

Giacomin, O., Janssen, F., Pruett, M., Shinnar, R. S., Llopis, F., \& Toney, B. (2011). Entrepreneurial intentions, motivations and barriers: Differences among American, Asian and European students. International Entrepreneurship and Management Journal, 7(2), 219-238. https://doi.org/10.1007/s11365-010-0155-y

Gieure, C., Benavides-Espinosa, M. del M., \& Roig-Dobon, S. (2019). Entrepreneurial intentions in an international university environment. International Journal of Entrepreneurial Behavior \& Research, 25(8), 1605-1620. https://doi.org/10.11 08/IJEBR-12-2018-0810

Hair, J. F., Jr., Howard, M. C., \& Nitzl, C. (2020). Assessing measurement model quality in PLS-SEM using confirmatory composite analysis. Journal of Business Research, 109, 101-110. https://doi.org/10.1016/j.jbusres.2019.11.069

Hair, J. F., Risher, J. J., Sarstedt, M., \& Ringle, C. M. (2019). When to use and how to report the results of PLS-SEM. European Business Review, 31 (1), 2-24. https://doi.org/10.1108/EBR-11-2018-0203

Hair Jr, J. F., Hult, G. T. M., Ringle, C. M., \& Sarstedt, M. (2021). A primer on partial least squares structural equation modeling (PLS-SEM). Sage publications. https://doi.org/10.1007/978-3-030-80519-7

Henseler, J., Ringle, C. M., \& Sarstedt, M. (2016a). Testing measurement invariance of composites using partial least squares. International Marketing Review, 33(3), 405-431. https://doi.org/10.1108/IMR-09-2014-0304

Henseler, J., Ringle, C. M., \& Sarstedt, M. (2015). A new criterion for assessing discriminant validity in variance-based structural equation modelling. Journal of the Academy of Marketing Science, 43(1), 115-135. https://doi.org/10.1007/s11747-0140403-8

Henseler, J., Hubona, G., \& Ray, P. A. (2016b). Using PLS path modeling in new technology research: updated guidelines. Industrial Management \& Data Systems, 116(1), 2-20. https://doi.org/10.1108/IMDS-09-2015-0382

Ho, M. H. R., Uy, M. A., Kang, B. N. Y., \& Chan, K. Y. (2018). Impact of Entrepreneurship Training on Entrepreneurial Efficacy and Alertness among Adolescent Youth. Frontiers in Education, Frontiers Media SA, 3.https://doi.org/10.33 89/feduc. 2018.00013

Hossain, M., \& Oparaocha, G. O. (2017). Crowdfunding: Motives, definitions, typology and ethical challenges. Entrepreneurship Research Journal, 7(2). https://doi.org/10.1515/erj-2015-0045

Islam, M. T., \& Khan, M. T. A. (2019). Factors influencing the adoption of crowdfunding in Bangladesh: A study of start-up entrepreneurs. Information Development, 37(1), 72-89. https://doi.org/10.1177\%2F0266666919895554

Jena, R. K. (2020). Measuring the impact of business management Student's attitude towards entrepreneurship education on entrepreneurial intention: A case study. Computers in Human Behavior, 107, 106275. https://doi.org/10.1016/j.chb. 2020.106275

Jones, P., Jones, A., Packham, G., \& Miller, C. (2008). Student attitudes towards enterprise education in Poland: a positive impact. In Nabi, G. (Ed.) Education + Training, Emerald, 50 (7), pp. 597-614. https://doi.org/10.1108/00400910810909054

Kang, M., Gao, Y., Wang, T., \& Zheng, H. (2016). Understanding the determinants of funders' investment intentions on crowdfunding platforms. Industrial Management \& Data Systems, 116(8), 1800-1819. https://doi.org/10.1108/IMDS-07-20150312

Karimi, S., Biemans, H. J. A., Lans, T., Chizari, M., \& Mulder, M. (2014). The Impact of Entrepreneurship Education: A Study of Iranian Students' Entrepreneurial Intentions and Opportunity Identification. Journal of Small Business Management, 54(1), 187-209. https://doi.org/10.1111/jsbm.12137

Khalilzadeh, J., Ozturk, A. B., \& Bilgihan, A. (2017). Security-related factors in extended UTAUT model for NFC based mobile payment in the restaurant industry. Computers in Human Behavior, 70, 460-474. https://doi.org/10.1016/j.chb.2017.01.001

Khursheed, A., Mustafa, F., Fatima, M., \& Siddique, F. (2018). Entrepreneurial Intentions: Gem Based Empirical Analysis on the Northern Europe and Asian Countries. International Journal of Entrepreneurial Knowledge, University College of Business in Prague, 6 (2). https://doi.org/10.37335/ijek.v6i2.78

Kim, M. J., Bonn, M., \& Lee, C. K. (2019). The effects of motivation, deterrents, trust, and risk on tourism crowdfunding behaviour. Asia Pacific Journal of Tourism Research, 25(3), 244-260. https://doi.org/10.1080/10941665.2019.1687533

Kim, M. J., \& Hall, C. M. (2020). What drives visitor economy crowdfunding? The effect of digital storytelling on unified theory of acceptance and use of technology. Tourism Management Perspectives, 34, 100638. https://doi.org/10.10 16/j.tmp.2020.100638

Kim, M. J., Hall, C. M., \& Kim, D. K. (2020). Why do investors participate in tourism incentive crowdfunding? The effects of attribution and trust on willingness to fund. Journal of Travel \& Tourism Marketing, 37(2), $141-154$. https://doi.org/10.1080/10548408.2020.1722784 
Kock, N. (2020). Using indicator correlation fit indices in PLS-SEM: Selecting the algorithm with the best fit. Data Analysis Perspectives Journal, 1(4), 1-4.

Krueger, N. F., JR, Reilly, M. D., \& Carsrud, A. L. (2000). Competing models of entrepreneurial intentions. Journal of Business Venturing, 15(5-6), 411-432. https://doi.org/10.1016/S0883-9026(98)00033-0

Kuselias, S. (2020). Follow the Crowd: How Social Information and Social Identity Influence Investing Decisions. Abacus, 56(3), 407-435. https://doi.org/10.1111/abac.12188

Laguia, A., Moriano, J. A., \& Gorgievski, M. J. (2019). A psychosocial study of self-perceived creativity and entrepreneurial intentions in a sample of university students. Thinking Skills and Creativity, 31, 44-57. https://psycnet.apa.org/doi/10.10 16/j.tsc.2018.11.004

Lee, S. M., Chang, D., \& Lim, S. B. (2005). Impact of entrepreneurship education: A comparative study of the US and Korea. The international entrepreneurship and management journal, 1(1), 27-43. https://doi.org/10.1007/s11365-005-6674-2

Linan, F., \& Chen, Y. (2009). Development and Cross-Cultural Application of a Specific Instrument to Measure Entrepreneurial Intentions. Entrepreneurship Theory and Practice, 33(3), 593-617. https://doi.org/10.1111\%2Fj.1540-6520.2009.00318.x

Meoli, A., Fini, R., Sobrero, M., \& Wiklund, J. (2020). How entrepreneurial intentions influence entrepreneurial career choices: The moderating influence of social context. Journal of Business Venturing, 35(3), 105982. https://oi.org/10.1016/ j.jbusvent.2019.105982

Mhango, M. W. (n.d.). Assessing entrepreneurial career intentions of family and consumer sciences students in higher education: a model testing approach. Iowa State University. https://doi.org/10.31274/rtd-180813-9928

Moon, Y., \& Hwang, J. (2018). Crowdfunding as an Alternative Means for Funding Sustainable Appropriate Technology: Acceptance Determinants of Backers. Sustainability, 10(5), 1456. https://doi.org/10.3390/su10051456

Moriano, J. A., Gorgievski, M., Laguna, M., Stephan, U., \& Zarafshani, K. (2011). A Cross-Cultural Approach to Understanding Entrepreneurial Intention. Journal of Career Development, 39(2), 162-185. https://doi.org/10.1177\%2F08948453 10384481

Munir, H., Jianfeng, C., \& Ramzan, S. (2019). Personality traits and theory of planned behavior comparison of entrepreneurial intentions between an emerging economy and a developing country. International Journal of Entrepreneurial Behavior \& Research, 25(3), 554-580. https://doi.org/10.1108/IJEBR-05-2018-0336

Ndofirepi, T. M. (2020). Relationship between entrepreneurship education and entrepreneurial goal intentions: psychological traits as mediators. Journal of Innovation and Entrepreneurship, Springer Science and Business Media LLC, 9 (1). https://doi.org/10.1186/s13731-020-0115-x

Nguyen, A. T., Do, T. H. H., Vu, T. B. T., Dang, K. A., \& Nguyen, H. L. (2019). Factors affecting entrepreneurial intentions among youths in Vietnam. Children and Youth Services Review, 99, 186-193. https://doi.org/10.1016/j.childyouth. 2019.01.039

Patil, P., Tamilmani, K., Rana, N. P., \& Raghavan, V. (2020). Understanding consumer adoption of mobile payment in India: Extending Meta-UTAUT model with personal innovativeness, anxiety, trust, and grievance redressal. International Journal of Information Management, 54, 102144. https://doi.org/10.1016/j.ijinfomgt.2020.102144

Paul, J., Hermel, P., \& Srivatava, A. (2017). Entrepreneurial intentions - theory and evidence from Asia, America, and Europe. Journal of International Entrepreneurship, 15(3), 324-351. https://doi.org/10.1007/s10843-017-0208-1

Perez-Fernandez, H., Delgado-Garcia, J. B., Martin-Cruz, N., \& Rodriguez-Escudero, A. I. (2020). The Role of Affect in the Development of Entrepreneurial Intentions. Entrepreneurship Research Journal, 1(ahead-of-print). https://doi.org/10.15 15/erj-2019-0124

Rodrigues, M., Silva, R., \& Franco, M. (2021). Entrepreneurial Attitude and Intention in Higher Education Students: What Factors Matter? Entrepreneurship Research Journal. https://doi.org/10.1515/erj-2020-0107

Rodriguez-Ricardo, Y., Sicilia, M., \& Lopez, M. (2019). Altruism and Internal Locus of Control as Determinants of the Intention to Participate in Crowdfunding: The Mediating Role of Trust. Journal of Theoretical and Applied Electronic Commerce Research, 14(3), 1-16. http://dx.doi.org/10.4067/S0718-18762019000300102

Roibu, I., \& Roibu, P. A. (2016). Barriers to women entrepreneurship: a comparative analysis between South Korea and Romania. Acta Universitatis Sapientiae, 8 (1), 183-203. https://doi.org/10.1515/ausp-2016-0013

Rossi, A., \& Vismara, S. (2018). What do crowdfunding platforms do? A comparison between investment-based platforms in Europe. Eurasian Business Review, 8(1), 93-118. https://doi.org/10.1007/s40821-017-0092-6

San Martin, H., Hernandez, B., \& Herrero, A. (2020). Social Consciousness and Perceived Risk as Drivers of Crowdfunding as a Socially Responsible Investment in Tourism. Journal of Travel Research, 60 (1), 16-30. https://doi.org/10.117 7\%2F0047287519896017

Schwienbacher, A. (2019). Equity crowdfunding: anything to celebrate? Venture Capital, 21(1), 65-74. https://doi.org/10.10 80/13691066.2018.1559010

Shinnar, R. S., Giacomin, O., \& Janssen, F. (2012). Entrepreneurial Perceptions and Intentions: The Role of Gender and Culture. Entrepreneurship Theory and Practice, 36(3), 465-493. https://doi.org/10.1111\%2Fj.1540-6520.2012.00509.x 
Shneor, R., Mrzyglod, U., Adamska-Mieruszewska, J., \& Fornalska-Skurczynska, A. (2021). The role of social trust in reward crowdfunding campaigns' design and success. Electronic Markets, Springer Science and Business Media LLC. https://doi.org/10.1007/s12525-021-00456-5

Smith, S., Hamilton, M., \& Fabian, K. (2019). Entrepreneurial drivers, barriers and enablers of computing students: gendered perspectives from an Australian and UK university. Studies in Higher Education, 45(9), 1892-1905. https://doi.org/10.1080/03075079.2019.1637840

Steigenberger, N. (2017). Why supporters contribute to reward-based crowdfunding. International Journal of Entrepreneurial Behavior \& Research, 23(2), 336-353. https://doi.org/10.1108/IJEBR-04-2016-0117

Stemler, A.R. (2013). The JOBS Act and crowdfunding: Harnessing the power-and money-of the masses. Business Horizons, 56(3), 271-275. https://doi.org/10.1016/j.bushor.2013.01.007

Thies, F., Wessel, M., \& Benlian, A. (2016). Effects of Social Interaction Dynamics on Platforms. Journal of Management Information Systems, 33(3), 843-873. https://doi.org/10.1080/07421222.2016.1243967

Venkatesh, Morris, Davis, \& Davis. (2003). User Acceptance of Information Technology: Toward a Unified View. MIS Quarterly, 27(3), 425. https://psycnet.apa.org/doi/10.2307/30036540

Wegner, D., Thomas, E., Teixeira, E. K., \& Maehler, A. E. (2019). University entrepreneurial push strategy and students' entrepreneurial intention. International Journal of Entrepreneurial Behavior \& Research, 26(2), 307-325. https://doi.org/10.110 8/IJEBR-10-2018-0648

Wei, X., Liu, X., \& Sha, J. (2019). How Does the Entrepreneurship Education Influence the Students' Innovation? Testing on the Multiple Mediation Model. Frontiers in Psychology, Frontiers Media SA, 10. https://doi.org/10.3389/fpsyg.2019.01557

Yang, X., Zhao, K., Tao, X., \& Shiu, E. (2019). Developing and Validating a Theory-Based Model of Crowdfunding Investment Intention-Perspectives from Social Exchange Theory and Customer Value Perspective. Sustainability, 11(9), 2525. https://doi.org/10.3390/su1 1092525

Zhao, Q., Chen, C. D., Wang, J. L., \& Chen, P. C. (2017). Determinants of backers' funding intention in crowdfunding: Social exchange theory and regulatory focus. Telematics and Informatics, 34(1), 370-384. http://dx.doi.org/10.1016/ j.tele.2016.06.006

Zheng, H., Hung, J.-L., Qi, Z., \& Xu, B. (2016). The role of trust management in reward-based crowdfunding. In Wu H. \& Guandong X. A. (Eds.), Online Information Review, 40 (1), 97-118. http://dx.doi.org/10.1108/OIR-04-2015-0099

\section{Authors' Biographies}

Mina Fanea-Ivanovici received a PhD in Economics in 2010. She is currently an Associate Professor at the Department of Economics and Economic Policies at the Bucharest University of Economic Studies. Her main research interests revolve around areas such as creative economy, creative industries, cultural economy, crowdfunding, digitalization, knowledge management, intercultural dialogue and intercultural competencies. She has published numerous articles and books and was a member of five research projects and director of one research grant. In 2016 she worked as an independent expert in charge of drafting and revisiting Romania's Strategy for Culture and National Heritage.

Hasnan Baber is currently working as an Assistant Professor in Endicott College of International Studies, Woosong University, South Korea. He has published numerous research papers through reputed publishers like Elsevier, Springer, Emerald, Sage, etc. His areas of research are Crowdfunding, FinTech, Behavioral Finance, Islamic Finance, and Service Quality. He has presented research papers and articles at various international conferences. He is also serving as an advisory and editorial board member of different reputed publishing houses.

The article has been reviewed.

Received in June 2021; accepted in December 2021.

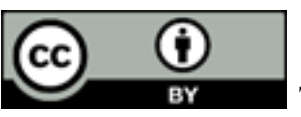

This article is an Open Access article distributed under the terms and conditions of the Creative Commons Attribution 4.0 (CC BY 4.0) License (http://creativecommons.org/licenses/by/4.0/). 